\title{
EFL Teachers' Familiarity with Post-Method: Considering Demographic Variables
}

\section{Bizhan Hekmatshoar Tabari $^{1 *} \&$ Bamshad Hekmatshoar Tabari ${ }^{2}$}

\section{* Correspondence: \\ bizhan_hekmat@yahoo.com \\ 1. Ayandegan Institute of Higher \\ Education, Tonekabon, Iran \\ 2. Imam Sadeq School (of Babol), \\ Technical and Vocational University, Iran}

Received: 21 May 2020

Revision: 23 July 2020

Accepted: 24 August 2020

Published online: 20 September 2020

\begin{abstract}
The present study intends to study Iranian EFL teachers' attitude towards post-method pedagogy (PMP) and its implementation in private language institutes. The participants of this study were 80 male and female EFL teachers from different private institutes in two cities of Mazandaran province in Iran. For the purpose of data collection, this study applied a Likert type questionnaire. In order to analyze it, minimum, maximum, mean, and standard deviation were calculated, then different tests including Friedman test, Wilcoxon test, Pearson Correlation, and Independent T-test were utilized. Considering the findings of the study, one cannot conclude that teachers have a positive attitude toward post-method principles. In fact, the findings show uncertainty about the actual emergence of PMP principles in EFL institutes in Iran and the fact that there is a long distance to the actual realization of principles of Particularity, Practicality, and Possibility, especially the last one. Furthermore, there is a significant relationship between respondent teachers' familiarity of some principles of PMP and their experience, field of study, and education degree.
\end{abstract}

Keywords: PMP, practicality, particularity, possibility, EFL teachers 


\section{Introduction}

From the late $19^{\text {th }}$ century to the late $20^{\text {th }}$ century, English language teaching field experienced different changes and movements, due to find solutions to problems concerning restrictions pertinent to different methods, which finally led to a gradual perception of Teaching English to Speakers of Other Languages (TESOL) community regarding the impracticality of methods and finally introducing an alternative that could go beyond limitations of the method paradigm. As a result, Post-Method Pedagogy (PMP) was born as a new movement, which dominated second language education.

According to Pennycook (1989), post-method, which is concerned with power and dominance, intends to reduce and resolve social inadequacies. PMP is a context-sensitive pedagogy, which has defined new roles and relationships for all involved in the process of learning and teaching, including learners and teachers, in accordance with the parameters of practicality, particularity, and possibility (Kumaravadivelu, 1994, 2001).

After the emergence of the so-called "death of the method" concept (Allwright, 1991) and the introduction of "postmethod condition" (Kumaravadivelu, 1994), which has not been unanimously agreed upon among scholars (Akbari, 2008), PMP has been gaining increased attention in the literature. The post-method debate attempted to remove the concept of method and trigger innovations in language teaching and learning. Post-method was defined by Kumaravadivelu (2006), based on three factors: an alternative to method, teacher as autonomous practitioner, and principled pragmatism. According to Bell (2007), post-method has been successful in its mission theoretically, but its practical aspect, that is methodology which happens actually in classroom has not been vanished from many classroom practitioners' discourses.

In order to explore what happens actually in classroom, teachers' perceptions and attitudes need to be investigated as one of the most crucial factors. As Freeman (1990) states, attitudes are so important that they can be considered as the main cause of teachers' failure or success. In fact, according to Clemente (2001), a holistic approach to teaching language considers how teachers feel about various aspects of their practice.

Due to the significance of teachers' attitudes in shaping their practice (Freeman, 1990; Hargreaves, 1994; Prabhu, 1992) and the roles which post-method pedagogy depicts for teachers and the relationship between teachers and theorizers by fostering teachers' skills, knowledge, and sense of autonomy (Kumaravadivelu, 2006), research on teachers' perceptions and attitudes regarding PMP seems necessary.

\subsection{Statement of the Problem}

Because of the importance of the relationship between teachers' beliefs, attitudes, and their classroom practices, examining the actual language teaching perceptions of teachers regarding post-method is considered crucial (Khany \& Darabi, 2014; Tasnimi, 2014). According to Rashidi and Mansourzadeh (2017), "teachers' understanding of postmethod pedagogy stands out as an appropriate example of the re-conceptualization of best teaching practices and it deserves to be studied seriously" (p.64). As Khodabakhshzadeh et al. (2018) state post-method pedagogy is still a new concept in Iran and more studies need to be done in this regard. Additionally, few studies have been done focusing on the actual implementation of parameters of PMP, i.e. Practicality, Particularity, and Possibility. Some studies have reported potentiality of PMP while others criticized its impracticality. In fact, actual existence or emergence of PMP is open to debate (Akbari, 2008; Bell, 2007; Larsen-Freeman, 2005; Lieu, 1995).

Therefore, the present research intends to study Iranian EFL teachers' attitudes towards PMP and its implementation in private language institutes in Iran. This research aims at studying the nature of activities, roles, and characteristics of language teachers to see the extent to which the basic principles of post-method have reached in English as a Foreign Language (EFL) language institute in Iran. In fact, there are two goals in this research: One to see if teachers are familiar with the basic principles of PMP to explore the extent of EFL teachers' familiarity with PMP principles. The second goal is to investigate if there is a significant relationship between teachers' attitudes in terms of their experience, age, gender, field of study, education degree, city, and institute.

\subsection{Research Questions}

The present study intended to answer the following questions:

- Do EFL teachers in private institutes have a positive attitude toward post-method principles?

- Are EFL teachers in private institutes familiar with the principles of PMP to the same amount? 
- Do private institute EFL teachers' attitudes of post- method principles differ significantly in terms of their experience, age, gender, field of study, education degree, city, and institute?

\subsection{Hypotheses of the Study}

Based on the above-mentioned research questions, the null hypotheses of the study are as follows:

- H1 (null): Teachers do not have a positive attitude toward post-method principles.

- H2 (null): There is not a significant difference between the familiarity extent of the teachers with each of the principles of PMP.

- H3 (null): Teachers' attitudes of post- method principles do not differ significantly in terms of their experience, age, gender, field of study, education degree, city and institute.

\section{Review of the Literature}

\subsection{Kumaravadivelu's PMP Framework}

As mentioned above, post-method is a reaction to the concept of method and aims to put an end to the search for the best method. Kumaravadivelu (2006) asserts, "the post-method condition is a sustainable state of affairs that compels us to fundamentally restructure our view of language teaching and teacher education" (p. 170). According to him, responsibility of post-method is to train teachers to be theorizers of their practice by empowering their skills, knowledge, and autonomy. Post-method has been defined by different scholars among which, Kumaravadivelu's conception is more acknowledged (Kumaravadivelu, 1999, 2001, 2003a, 2003b). Kumaravadivelu (2006) enumerates three principles as the building blocks of PMP namely particularity, practicality, and possibility. These principles are explained briefly as follows:

Particularity: It is the backbone of PMP which emphasizes that the role of context or situation is central to meaningful pedagogy. It focuses on "local exigencies and lived experiences" (p. 171). Kumaravadivelu (2006) believes that we "must be sensitive to a particular group of teachers teaching a particular group of learners pursuing a particular set of goals within a particular institutional context embedded in a particular socio-cultural milieu" (p. 171). In this sense, context plays a vital role in PMP.

Practicality: This aspect is concerned with the relation between theory and practice. In fact, one of the disadvantages of language teaching has been the gap between professional theories of the researchers and personal theories of the practitioners. Practicality intends to bridge this gap as much as possible proposing techniques such as action research.

Possibility: It is related to the extent to which one's understanding of himself and the society and the world he lives in is actually influenced by the language he speaks or learns. This has been a concern of sociopolitical aspect of English Language Teaching (ELT) in post-method era, i.e. the view that language forms the power relationships and social structures of a society (Gholami et al., 2012).

\subsection{Review of Relevant Studies}

According to Akbari (2008), "missing from post-method is how teachers are prepared to perform their duties as postmethod practitioners because post-method view heavily emphasizes teacher qualifications" (p. 642). He also concluded that post-method pedagogy would have occurred if multilateral changes had happened within the academic community in Iran including foundations of teacher education, certification, norms of practice, standardization of language tests, and hiring and firing policies.

In an investigation into novice teachers' beliefs about method and post-method, Tekin (2013) found that the majority of participants in his study were unaware of what PMP was; some believing it equated to eclecticism, and only one being aware of its key tenet, which Tekin (Ibid) identified as 'no best method.' In a similar line of enquiry, Saengboon (2013) set out to uncover 6 EFL lecturers' understanding of PMP in Thailand, and deduced from interview responses that they were aware of the main concept even though they were unable to articulate it directly. Gholami and Mirzaei (2013) carried out a study on the teaching strategies teachers applied in their classes as the symbols of PMP in Iranian EFL context of private language schools. According to the findings of the survey, EFL teachers in Iran were aware of the achievements of post-method era, but they faced with many barriers that impeded their actual implementation of PMP. 
Razjmoo et al. (2013) attempted to investigate PMP's actual appearance based on the parameters of particularity, possibility, and practicality as an EFL context in the English language institutes all over Shiraz, Iran. The findings of the study questioned feasibility, possibility, or practicality of a completely post-method based teaching pedagogy and its emergence into Iranian context. In fact, there was a long distance to the actual manifestation of post-method principles, especially its possibility and practicality parameters. The findings also showed that teaching in Iran was mainly based on eclectic teaching. Khany and Darabi (2014) conducted a study to explore the reflection of principlesbased and PMP in teachers' performance in the classroom in Iranian ELT context of different high schools in Kermanshah, Ilam, and Tehran. The results determined that principles of PMP were not highly applied to teachers' performance in the classroom. Additionally, the effects of other factors like teaching experience, education level, and gender on teachers' performance were investigated.

Shafiei and Zoghi (2014) conducted a research on EFL teachers' attitudes towards methods and post-method on second language learning production with regard to accuracy and planning type. In this study, the participants consisted of EFL teachers teaching at three language institutes in Tabriz city in Iran. This study tried to explore the possibility of any correlation between the teachers' teaching experience and their attitudes towards the present post-methods. The findings of the study suggested that language teachers' knowledge of post-method methodology seemed to be an important factor in determining the importance of their teaching.

Khatib and Fathi (2014) explored the perspectives of the Iranian EFL domain experts about PMP. The findings of this study raised much doubt and uncertainty about both method and PMP. According to the results, the Iranian language education had never experienced method in its actual meaning. In fact, teachers had adhered to eclectic approach, simply based on their personal tastes. Furthermore, the findings of the Delphi technique revealed that post-method pedagogy with its three principles was not applicable in the Iranian context. From this angle, this study verified the findings of other similar studies (Gholami \& Mirzaei, 2013; Razmjoo et al., 2013) that the healthy existence of postmethod as proposed based on the principles of particularity, practicality, and possibility seemed to be too idealistic and far-reaching.

Safari and Rashidi (2015) intended to extract English teachers' practical constraints and barriers in applying postmethod as a new EFL pedagogy in Iran. Experienced English teachers from high schools of Yazd and Shiraz, Iran, participated in this research. The research found that the application of PMP in the Iranian EFL context was not a simple job. In fact, in the case of 'particularity' and 'practicality', as two components of Kumaravadivelu's (2006) tripartite framework, it might be possible to introduce this pedagogy through a great amount of financial investment, instruction, the provision of resources and opportunities, but it would still be nearly impossible based on possibility 'principle.' The difficulty with this parameter was concerned with the sociopolitical factors and critical thinking dimensions which had not been considered in Iranian education and culture.

Maghsoudi (2016) tried to shed light on the present status of PMP in Iran. She examined different studies that had been carried out in EFL context of Iran such as Akbari (2008), Fahim and Pishghadam (2009), Hazratzadeh and Gheitanchian (2009), Hashemi (2011), and Gholami and Mirzaei (2013), and concluded that "It seems very far-fetched to expect post- method to emerge out of the centralized system of education unless an extensive shift of policies occurs within the limiting conditions of ELT in Iran." Mardani and Moradian (2016) conducted a research which intended to verify actual appearance of PMP dealing with the implementation of post-method parameters of particularity, possibility, and practicality and existing barriers which impede implementing it in Iranian private language schools. The results of the survey indicated that in spite of Iranian EFL teachers' awareness of the achievements of post-method era, they faced with many limitations in implementing teaching based on its criteria.

NaseriKaimvand et al. (2016) endeavored to unveil the perception of Iranian EFL teachers on the applicability of postmethod. The data analysis of the importance of teacher's active involvement in post-method procedure showed that $37 \%$ of the participants thought this involvement was 'moderately important', and $19 \%$ of them considered it 'very important.' Additionally, according to the descriptive analysis of the factor of possibility, $37 \%$ of the respondents regarded following the parameter of possibility in their teaching as 'rarely possible', and $18 \%$ thought it was 'impossible.' The analysis of the results of the interview also revealed that language centers and supervisors were among the facilitative factors and time limitation and students' lack of interest were among the challenges in implementing PMP.

Aboulalaei et al. (2016) set out a study about the role of post-method, teachers' familiarity with it, and how it affected their teaching and learning to explore any correlation between the field of study taught and the teachers' attitudes 
towards the post-method strategies. The teachers were selected from an English language institute located in Tabriz, Iran. Based on the results, it was supported that language teachers' knowledge and awareness of post-method seemed to play out as an important factor in their teaching. The findings also had certain, pedagogical and theoretical implications in second language teaching and second language learning assessment.

Shafiqul Islam and Shuchi (2017) addressed limitations and challenges of PMP regarding its applicability in EFL context. According to the authors, among many factors that restricted applicability of PMP, teachers' lack of required knowledge or skill to teach in the post-method fashion was referred to as one of the most important ones. Different studies have been carried out on the realization of post-method and its implementation in Iran. In general, most of them conclude that there is a long way to the actual implementation of PMP in this context. But, as Maghsoudi (2016) states, much more research needs to be done regarding this issue because "the current status of post-method in EFL contexts is considered controversial by many researchers and teachers" (p.287). In addition, it seems that more studies need to focus on EFL teachers' attitudes in English language institutes in Iran.

\section{Methodology}

In this part, the design of the study, participants, instrument, sampling, data collection, and data analysis of the study are explained in detail.

\subsection{Design of the study}

Due to the difficulty in samples availability, convenience-sampling technique was used in this study. The present study adopted survey research design in which an opinion questionnaire was utilized for the purpose of data collection. In fact, in order to investigate teachers' familiarity with PMP principles of particularity, practicality, possibility, the role of teachers, and the role of learners, this study applied a quantitative approach in which the participants' responses to multiple-choice items in a likert-type questionnaire were explored.

\subsection{Participants}

80 EFL teachers from different private institutes in two cities of Mazandaran province in Iran, participated in this research based on their availability. The participants were from two cities of Babol and Tonekabon, the most populated cities in east and west of this province respectively. 41 of the teachers were from Babol and 39 from Tonekabon. There were 48 female and 32 male teachers. They ranged in age from 20 to 60 with a mean age of 32 . They had from 1 to 30 years of teaching experience with an average of 9 years. 20 teachers held B.A degree, 28 teachers held M.A. and the rest had $\mathrm{PhD}$ or were $\mathrm{PhD}$ candidates. 76 teachers out of 80 studied English and 4 teachers' field of study were not English. Among those 76 teachers whose major were English, 60 teachers studied Teaching English as a Foreign Language (TEFL), 12 teachers studied Translation, 4 of them Literature. 10 of them taught at Iran Language Institute (ILI) and the rest at other institutes. Demographic information of the participants is summarized as follows:

Table 1. Frequencies of teacher demographic data

\begin{tabular}{llll}
\hline Variable & Categories & Frequency & Percentage \\
\hline Gender & Male & 32 & 40 \\
& Female & 48 & 60 \\
\hline Age & $20-30$ & 34 & 42.5 \\
& $30-40$ & 36 & 45 \\
& $40-50$ & 8 & 10 \\
& $50-60$ & 2 & 2.5 \\
\hline Education Degree & B.A. & 22 & 27.5 \\
& M.A. & 28 & 35 \\
& PhD/PhD Candidate & 30 & 37.5
\end{tabular}




\begin{tabular}{|c|c|c|c|c|}
\hline \multirow[t]{4}{*}{ Field of Study } & TEFL & & 60 & 75 \\
\hline & Translation & & 12 & 15 \\
\hline & Literature & & 4 & 5 \\
\hline & others & & 4 & 5 \\
\hline \multirow[t]{3}{*}{ Teaching Experience } & $0-10$ & & 52 & 65 \\
\hline & $10-20$ & & 24 & 30 \\
\hline & $20-30$ & & 4 & 5 \\
\hline \multirow[t]{2}{*}{ City } & Babol & & 45 & 56.25 \\
\hline & Tonekabon & & 35 & 43.75 \\
\hline \multirow[t]{2}{*}{ Institute } & $\begin{array}{l}\text { ILI (Iran } \\
\text { Institute) }\end{array}$ & Language & 10 & 12.5 \\
\hline & others & & 70 & 87.5 \\
\hline
\end{tabular}

\subsection{Instrument}

For this study, the researchers used a Likert-type questionnaire, which was constructed and tested before by Razmjoo, et al. (2013), so the validity and reliability of this questionnaire were previously determined. For the purpose of validity, a pilot study was done. All the items of the questionnaire were randomized and distributed among 154 institute teachers. After collecting the data, the researchers calculated the validity coefficients in terms of factor analysis (Table 2).

Table 2. Confirmatory Factor Analysis of the questionnaire

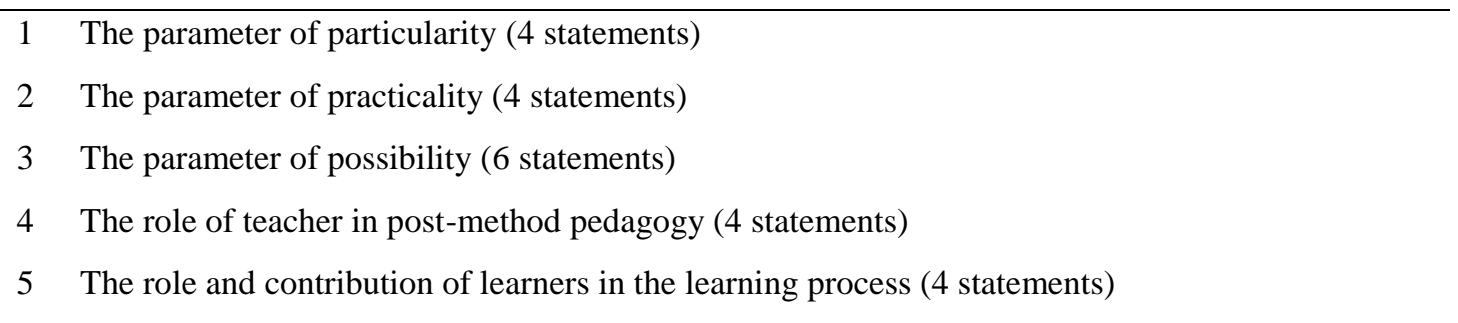

In order to calculate the reliability of the questionnaire, the researchers used Cronbach's alpha. Applying SPSS software, the overall internal consistency of the questionnaire estimated to be 0.888 . The likert-type questionnaire which was used in this study, consisted of two sections. The first one was related to the participants' personal information and the second part intended to investigate teachers' familiarity with PMP principles.

3.3.1 The first section of the questionnaire

This part was supposed to elicit the teachers' demographic information including, their sex or gender, age, years of teaching experience in English Institutes, major and university degree, and the city and the name of the institutes in which they were teaching.

\subsubsection{The second section of the questionnaire}

This part contained some items about the main tenets of PMP namely the principles of particularity, practicality, possibility, the role of teachers, and the role of learners. It consisted of 22 items ( 11 favorable and 11 unfavorable) on the Likert scale. Each statement had 4 possible responses: 'strongly agree', 'agree', 'disagree', and 'strongly disagree.' 
The highest score on the scale (4) was for 'strongly disagree', which indicated a favorable attitude; 3 for 'disagree', 2 for 'agree' and 1 for 'strongly agree.'

\subsection{Procedure of the Study}

The participants of this study were selected through convenience-sampling, a non-probability sampling technique, in which the samples are chosen based on their availability in terms of certain time or geographical proximity (Dörnyei \& Csizer, 2012). In the present study, this sampling was adopted, since it could make the collection process easier for two reasons: 1) The two cities from which the data were collected, had the most number of EFL private institutes in Mazandaran province, and 2) Each of the researchers lived in one of these two cities.

Before distributing the questionnaire among the teachers at their institute, the researchers talked to the institute principals and explained the purpose of the study for permission and cooperation. After that, the institute teachers were informed about the purposes of the study and they were told that their answers would remain confidential. At the participants' request, they were given sufficient time to answer the questionnaires. Thus, the researchers asked the principals to receive the filled questionnaires. Upon their call, the questionnaires were collected. At last, descriptive and inferential analyses were done accordingly.

\subsection{Data Collection}

In order to collect the data, a Likert-type questionnaire was used which intended to seek teachers' familiarity with PMP principles. Hence it is the rule of research to inform the participants that their answers would remain confidential, the participants were informed by the researchers that their answers would be used only for the purposes of the research in order to develop learning and teaching in EFL contexts. The researchers distributed the questionnaires among the EFL teachers of different Institutes in two cities of Babol and Tonekabon in Mazandaran Province in Iran and then, they were collected for the purpose of analysis.

\subsection{Data Analysis}

After collecting the participants' answers to the questionnaire, they were entered into and analyzed by SPSS statistical software. First, in order to have descriptive analysis of the data, minimum, maximum, mean, and standard deviation were calculated, then for the purpose of inferential analysis, Friedman test, Wilcoxon test, Pearson Correlation, and Independent T-test have been utilized.

\section{Findings}

The findings of the study are presented and explained in this section.

\subsection{The First Hypothesis}

For answering the first question of this study, that is to check respondent teachers' attitudes about the principles representing post-method pedagogy, the answers to the items of the questionnaire were calculated in terms of frequency and percentage. Then, the respondents' answers to the items, the first two (strongly agree and agree) and the last two (disagree and strongly disagree) were added up together in order to have a better picture and interpretation (Table 3). 
Table 3. Teachers' attitude toward teaching principles in Terms of Frequency (F) and Percentage (P)

\begin{tabular}{|c|c|c|c|c|c|}
\hline \multirow{2}{*}{ number } & \multirow{2}{*}{ Item } & \multicolumn{2}{|c|}{$\mathrm{SA}+\mathrm{A}$} & \multicolumn{2}{|c|}{$\mathrm{D}+\mathrm{SD}$} \\
\hline & & $\mathrm{F}$ & $\mathrm{P}$ & $\mathrm{F}$ & $\mathrm{P}$ \\
\hline 1 & My role is to transmit knowledge without altering the content. & 32 & 40 & 48 & 60 \\
\hline 2 & I give learners institutional, political, social and cultural awareness. & 62 & 77.5 & 18 & 22.5 \\
\hline 3 & I cannot generate my own theories to teach in class. & 26 & 32.5 & 54 & 67.5 \\
\hline 4 & $\begin{array}{l}\text { I am not interested in the sociopolitical context and its power } \\
\text { dimensions. }\end{array}$ & 31 & 38.75 & 49 & 61.25 \\
\hline 5 & $\begin{array}{l}\text { My teaching is in line with the notion that every class context is } \\
\text { unique. }\end{array}$ & 72 & 90 & 8 & 10 \\
\hline 6 & My role is to help students gain a sense of ownership of education. & 75 & 93.75 & 5 & 6.25 \\
\hline 7 & My teaching does not vary from context to context. & 14 & 17.5 & 66 & 82.5 \\
\hline 8 & My learners do not have a role in pedagogic decision making. & 18 & 22.5 & 62 & 77.5 \\
\hline 9 & I have a fair degree of autonomy in pedagogic decision- making. & 64 & 80 & 16 & 20 \\
\hline 10 & I'm not interested in sociopolitical issues in my classes. & 29 & 36.25 & 51 & 63.75 \\
\hline 11 & $\begin{array}{l}\text { I observe, analyze, and evaluate my teaching to generate my own } \\
\text { theories. }\end{array}$ & 66 & 82.5 & 14 & 17.5 \\
\hline 12 & My learners do not search for language beyond the classroom. & 36 & 45 & 44 & 55 \\
\hline 13 & $\begin{array}{l}\text { My teaching is sensitive to a particular group of learners in a } \\
\text { particular institutional or sociocultural context. }\end{array}$ & 43 & 53.75 & 37 & 46.25 \\
\hline 14 & I generate my own theory of teaching. & 59 & 73.75 & 21 & 26.25 \\
\hline 15 & $\begin{array}{l}\text { I try to tap the sociopolitical consciousness of learners as change } \\
\text { agents. }\end{array}$ & 48 & 60 & 32 & 40 \\
\hline 16 & $\begin{array}{l}\text { I try to bring about social, cultural, and political change and } \\
\text { transformation. }\end{array}$ & 45 & 56.25 & 35 & 43.75 \\
\hline 17 & $\begin{array}{l}\text { I do not adjust my teaching to the particular conditions of different } \\
\text { contexts. }\end{array}$ & 20 & 25 & 60 & 75 \\
\hline 18 & My learners are active and autonomous. & 57 & 71.25 & 23 & 28.75 \\
\hline 19 & I am not interested in making my own theory of practice. & 21 & 26.25 & 59 & 73.7 \\
\hline 20 & $\begin{array}{l}\text { I do not encourage learners to investigate how language as ideology } \\
\text { serves vested interests. }\end{array}$ & 17 & 21.25 & 63 & 78.75 \\
\hline 21 & $\begin{array}{l}\text { The system does not recognize my role to teach autonomously within } \\
\text { constraints of institutions, curricula, and textbooks. }\end{array}$ & 33 & 41.25 & 48 & 58.75 \\
\hline 22 & My learners explore the Internet and bring to class their own topics. & 56 & 70 & 24 & 30 \\
\hline
\end{tabular}


Since items $1,3,4,7,8,10,12,17,19,20$, and 21 are negative, their results interpreted reversely for interpretation. The maximum and minimum score, which imply the highest and lowest degree of conformity to the tenets of PMP, equal 88 and 22, respectively. Thus, the participants' responses fall between the range of 22 to 88 and the neutral point is 55. The mean of the questionnaire items mounted to 56.86 and the standard deviation was 8.85. Because the mean is less than half the standard deviation over the neutral point, the first (null) hypothesis is supported. Thus, one cannot conclude that teachers have a positive attitude toward post-method principles.

\subsection{The Second Hypothesis}

In order to explore the extent of agreement or familiarity of the teachers with each of the 5 principles of PMP, that is to see if teachers are familiar with all the 5 principles to the same amount, first, the items of the questionnaire were grouped in terms of those 5 parameters of PMP (Table 4).

Table 4. Confirmatory factor analysis of the questionnaire

\begin{tabular}{ll}
\hline Principles & Items \\
\hline 1. Particularity & $5,7,13 \& 17$ \\
2. Practicality & $3,11,14 \& 19$ \\
3. Possibility & $2,4,10,15,16 \& 20$ \\
4. Teacher role & $1,6,9 \& 21$ \\
5. Learner role & $8,12,18 \& 22$ \\
\hline
\end{tabular}

After that, Friedman test was applied. As it is shown in Table 4, Level of significance $<0.05$, thus the second (null) hypothesis is rejected; that is, there is a significant difference between the familiarity extent of the teachers with each of the 5 principles. In fact, teachers agree with the 5 principles differently (Table 5).

Table 5. Friedman test results

\begin{tabular}{llll}
\hline Principle & Mean Rank & results & rank \\
\hline Particularity & 3.51 & & $(1)$ \\
Practicality & 3.24 & Chi-Square=17.939 & $(2)$ \\
Teacher role & 2.79 & Df $=4$ & $(3)$ \\
Learner role & 2.79 & Sig. $=0.001$ & $(4)$ \\
Possibility & 2.66 & & $(5)$ \\
\hline
\end{tabular}

The result of Friedman test shows that respondent teachers agree with particularity, which deals with the importance of context, more than other principles; and possibility, which emphasizes the socio-political aspect, is fallen at the bottom of the rank. Furthermore, teachers have the same familiarity toward teacher role and learner role.

The result of Wilcoxon test, which compares all the principles two by two, reveals that there is not a significant difference between the familiarity of particularity and practicality and they get first rank (a). In addition, there is not a significant difference between teachers' role and learners' role and they posit second rank (b), and the familiarity of possibility stands at third rank (c) (Diagram 1). 


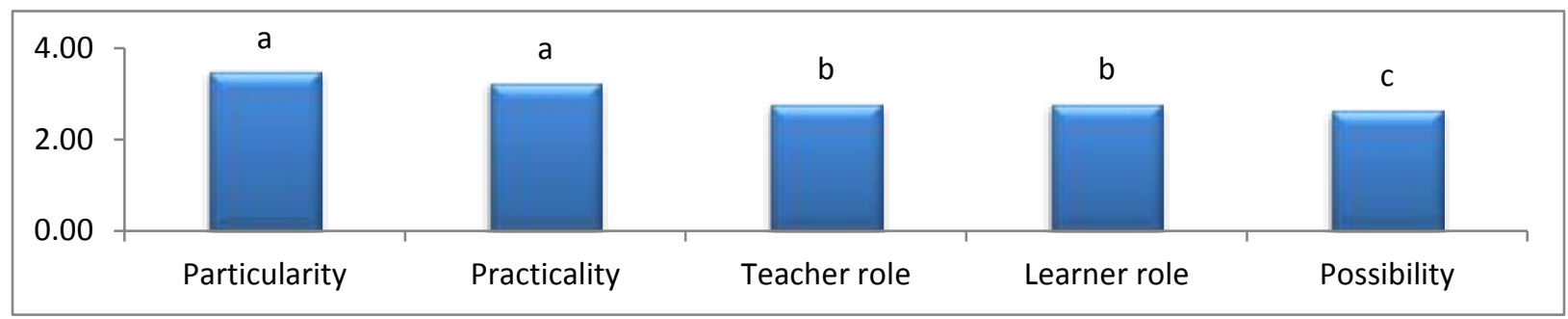

Diagram 1. Wilcoxon test results

\subsection{The Third Hypothesis}

In order to investigate the possible relationship between teachers' attitudes toward each of the five principles of PMP and their teaching experience and age, Pearson correlation is used and for gender, field of study, education degree, city, and institute, independent t-test is applied. The results indicate that there is not a significant relationship between teachers' attitudes toward each of the five principles of PMP and gender, age, city, and institute, since level of significance is not $<0.05$, thus the third (null) hypothesis is supported about them. But for teaching experience, field of study and education degree, the results show significance in relation to some parameters. The related analysis of these factors is presented individually.

\subsubsection{Gender}

According to Table 6, the results of Independent t-test reveal that there is not a significant relationship between teachers' attitudes toward each of the five principles of PMP and gender, because level of significance regarding each case is not less than 0.05 .

Table 6. Independent t-test results

\begin{tabular}{llllllll}
\hline & gender & $\mathrm{N}$ & Mean & Std. Deviation & t-value & df & Sig. \\
\hline Particularity & male & 33 & 12.3636 & 2.13334 & 0.822 & 78 & 0.414 \\
& female & 47 & 12.0213 & 1.59468 & & & \\
Practicality & male & 33 & 11.9394 & 2.34440 & 0.325 & 78 & 0.746 \\
& female & 47 & 11.7872 & 1.84080 & & & \\
Possibility & male & 33 & 17.3030 & 3.58369 & 1.362 & 78 & 0.177 \\
\multirow{2}{*}{ Teacher role } & female & 47 & 16.3617 & 2.59954 & & & \\
& male & 33 & 11.2424 & 1.87133 & 0.020 & 78 & 0.984 \\
Learner role & female & 47 & 11.2340 & 1.80835 & & & \\
& male & 33 & 10.9394 & 3.05102 & -0.390 & 78 & 0.697 \\
\hline
\end{tabular}

\subsubsection{Age}

The results of Pearson Correlation test show that there is not a significant relationship between teachers' attitudes toward each of the five principles of PMP and age, because level of significance regarding each case is not less than 0.05 (Table 7). 
Table 7. Correlation results

\begin{tabular}{lllllll}
\hline & & Particularity & Practicality & Possibility & Teacher role & Learner role \\
\hline \multirow{3}{*}{ Age } & Pearson Correlation & 0.209 & 0.017 & 0.083 & -0.028 & 0.023 \\
& Sig. & 0.063 & 0.883 & 0.463 & 0.802 & 0.841 \\
& $\mathrm{~N}$ & 80 & 80 & 80 & 80 & 80 \\
\hline
\end{tabular}

\subsubsection{City}

As it is shown in Table 8, there is not a significant relationship between teachers' attitudes toward each of the five principles of PMP and respondent teachers' city, because level of significance regarding each case is not less than 0.05 .

Table 8. Independent t-test results

\begin{tabular}{llllllll}
\hline & city & $\mathrm{N}$ & Mean & Std. Deviation & t-value & df & Sig. \\
\hline \multirow{2}{*}{ Particularity } & Babol & 41 & 12.1463 & 2.08040 & -0.080 & 78 & 0.936 \\
& Tonekabon & 39 & 12.1795 & 1.55380 & & & \\
\cline { 2 - 7 } Practicality & Babol & 41 & 11.8780 & 2.05177 & & & \\
& Tonekabon & 39 & 11.8205 & 2.07582 & 0.125 & 78 & 0.901 \\
Possibility & Babol & 41 & 16.8293 & 3.19298 & & & \\
\multirow{2}{*}{ Teacher role } & Tonekabon & 39 & 16.6667 & 2.94987 & 0.236 & 78 & 0.814 \\
& Babol & 41 & 11.1220 & 2.02725 & & & \\
Learner role & Tonekabon & 39 & 11.3590 & 1.59748 & -0.579 & 78 & 0.564 \\
\cline { 2 - 7 } & Babol & 41 & 10.8537 & 2.50560 & & & \\
\hline
\end{tabular}

\subsubsection{Institute}

There is not a significant relationship between teachers' attitudes toward each of the five principles of PMP and the institute they teach in, because level of significance regarding each case is not less than 0.05 . In fact, attitude of ILI teachers and those who teach in other institutes toward principles of PMP is not significantly different (Table 9). 
Table 9. Independent t-test results

\begin{tabular}{|c|c|c|c|c|c|c|c|}
\hline & Institute & $\mathrm{N}$ & Mean & Std. Deviation & t-value & df & Sig. \\
\hline \multirow{2}{*}{ Particularity } & ILI(Iran Language Institute) & 11 & 12.5455 & 1.86353 & \multirow{2}{*}{0.745} & \multirow{2}{*}{78} & \multirow{2}{*}{0.459} \\
\hline & Others & 69 & 12.1014 & 1.83227 & & & \\
\hline \multirow{2}{*}{ Practicality } & $\overline{\mathrm{ILI}}$ & 11 & 11.7273 & 1.00905 & \multirow{2}{*}{-0.212} & \multirow{2}{*}{78} & \multirow{2}{*}{0.832} \\
\hline & Others & 69 & 11.8696 & 2.17549 & & & \\
\hline \multirow{2}{*}{ Possibility } & $\overline{\mathrm{ILI}}$ & 11 & 15.8182 & 3.57262 & \multirow{2}{*}{-1.089} & \multirow{2}{*}{78} & \multirow{2}{*}{0.279} \\
\hline & Others & 69 & 16.8986 & 2.97116 & & & \\
\hline \multirow{2}{*}{ Teacher role } & $\overline{\mathrm{ILI}}$ & 11 & 11.0909 & 1.57826 & \multirow{2}{*}{-0.286} & \multirow{2}{*}{78} & \multirow{2}{*}{0.776} \\
\hline & Others & 69 & 11.2609 & 1.86809 & & & \\
\hline \multirow{2}{*}{ Learner role } & $\overline{\mathrm{ILI}}$ & 11 & 11.0000 & 2.14476 & \multirow{2}{*}{-0.103} & \multirow{2}{*}{78} & \multirow{2}{*}{0.918} \\
\hline & Others & 69 & 11.0870 & 2.66645 & & & \\
\hline
\end{tabular}

\subsubsection{Teaching Experience}

As it is shown in Table 10, level of significance is less than 0.05. Thus, the third (null) hypothesis is rejected, that is there is a significant relationship between teaching experience (years of teaching) and parameter of particularity which deals with the importance of context, that is more experienced teachers agree with particularity more than inexperienced ones. In fact, agreement or familiarity with particularity (i.e. importance of context) increases with increasing teaching experience.

Table 10. Correlation results

\begin{tabular}{lllllll}
\hline & Particularity & Practicality & Possibility & Teacher role & Learner role \\
\hline Experience & Pearson Correlation & $0.274^{*}$ & 0.104 & 0.103 & 0.074 & 0.003 \\
& Sig. & 0.014 & 0.358 & 0.362 & 0.513 & 0.977 \\
& $\mathrm{~N}$ & 80 & 80 & 80 & 80 & 80 \\
\hline
\end{tabular}




\subsubsection{Field of Study}

Table 11. Independent t-test results

\begin{tabular}{|c|c|c|c|c|c|c|c|}
\hline & Field of study & $\mathrm{N}$ & Mean & Std. Deviation & t-value & $\mathrm{df}$ & Sig. \\
\hline \multirow{2}{*}{ Particularity } & TEFL & 60 & 12.4167 & 1.89819 & \multirow{2}{*}{2.202} & \multirow{2}{*}{78} & \multirow{2}{*}{0.031} \\
\hline & Others & 20 & 11.4000 & 1.39170 & & & \\
\hline \multirow{2}{*}{ Practicality } & $\overline{\text { TEFL }}$ & 60 & 12.0833 & 2.17296 & \multirow{2}{*}{1.787} & \multirow{2}{*}{78} & \multirow{2}{*}{0.078} \\
\hline & Others & 20 & 11.1500 & 1.46089 & & & \\
\hline \multirow{2}{*}{ Possibility } & $\overline{\mathrm{TEFL}}$ & 60 & 17.1000 & 3.24011 & \multirow{2}{*}{1.798} & \multirow{2}{*}{78} & \multirow{2}{*}{0.076} \\
\hline & Others & 20 & 15.7000 & 2.17885 & & & \\
\hline \multirow{2}{*}{ Teacher role } & TEFL & 60 & 11.4000 & 1.88841 & \multirow{2}{*}{1.389} & \multirow{2}{*}{78} & \multirow{2}{*}{0.169} \\
\hline & Others & 20 & 10.7500 & 1.55174 & & & \\
\hline \multirow{2}{*}{ Learner role } & $\overline{\text { TEFL }}$ & 60 & 11.1333 & 2.72755 & \multirow{2}{*}{0.347} & \multirow{2}{*}{78} & \multirow{2}{*}{0.729} \\
\hline & Others & 20 & 10.9000 & 2.17401 & & & \\
\hline
\end{tabular}

According to Table 11, there is a significant relationship between teachers' attitude of particularity (which deals with importance of context) and their field of study, for level of significance is less than 0.05. Thus, the third (null) hypothesis is rejected, that is teachers whose majors are TEFL are familiar with particularity more than others.

\subsubsection{Education Degree}

As it is seen in Table 12, there is a significant relationship between teachers' attitude of particularity (which highlights importance of context), practicality (which stresses the importance of involving teacher-generated theories of practice), and learner role and their degree, since level of significance is less than 0.05 . Thus, the third (null) hypothesis is rejected, that is post-graduated teachers (those with M.A. and $\mathrm{PhD}$ ) are familiar or agree with these variables more than B.A. holders. In fact, education degree plays an important role in familiarity of the teachers with tenets of PMP except Possibility, which is concerned with socio-political aspect of ELT.

Table 12. Independent t-test results

\begin{tabular}{|c|c|c|c|c|c|c|c|}
\hline & Degree & $\mathrm{N}$ & Mean & Std. Deviation & t-value & $\mathrm{df}$ & Sig. \\
\hline \multirow{2}{*}{ Particularity } & B.A. & 16 & 11.1875 & 1.47054 & \multirow{2}{*}{-2.456} & \multirow{2}{*}{78} & \multirow{2}{*}{0.016} \\
\hline & M.A. \& PhD & 64 & 12.4063 & 1.84062 & & & \\
\hline \multirow{2}{*}{ Practicality } & B.A. & 16 & 10.6875 & 1.66208 & \multirow{2}{*}{-2.628} & \multirow{2}{*}{78} & \multirow{2}{*}{0.010} \\
\hline & M.A. \& PhD & 64 & 12.1406 & 2.04604 & & & \\
\hline \multirow{2}{*}{ Possibility } & B.A. & 16 & 15.8125 & 2.07264 & \multirow{2}{*}{-1.379} & \multirow{2}{*}{78} & \multirow{2}{*}{0.172} \\
\hline & M.A. \& PhD & 64 & 16.9844 & 3.22929 & & & \\
\hline \multirow{2}{*}{ Teacher role } & B.A. & 16 & 10.8125 & 1.86971 & \multirow{2}{*}{-1.043} & \multirow{2}{*}{78} & \multirow{2}{*}{0.300} \\
\hline & M.A. \& PhD & 64 & 11.3438 & 1.81019 & & & \\
\hline \multirow{2}{*}{ Learner role } & B.A. & 16 & 9.7500 & 2.48998 & \multirow{2}{*}{-2.354} & \multirow{2}{*}{78} & \multirow{2}{*}{0.021} \\
\hline & M.A. \& PhD & 64 & 11.4063 & 2.52429 & & & \\
\hline
\end{tabular}




\section{Discussion}

According to the statistical analyses of this study, the first hypothesis 'teachers do not have a positive attitude toward post-method principles' was supported. Thus, it cannot be concluded that teachers have a positive attitude toward post-method principles. In fact, the results of this part of the study are in line with the findings of some studies (Razmjoo et al. (2013), Mardani and Moradian (2016), and Naseri Kaimvand (2016), which reported that there is uncertainty about the actual emergence of PMP principles in EFL institutes in Iran and that there is a long distance to the actual realization of PMP.

Based on the results of the study analyses, the second hypothesis 'there is not a significant difference between the familiarity extents of the teachers with each of the principles of PMP' was rejected, that is there is a significant difference between the familiarity extents of the teachers with each of the principles of PMP. In other words, it seems that teachers in private institutes do not agree with the principles of PMP to the same amount. The findings revealed that respondent teachers agreed with particularity, which deals with the importance of context, more than other principles; and possibility, which emphasizes the socio-political aspect, less than others. Furthermore, there is not a significant difference between the familiarity of particularity and practicality.

The results of this part of the study are consistent with Safari and Rashidi (2015) who asserted that the application of PMP in the case of 'particularity' and 'practicality', might be difficult but possible through a great amount of financial investment, instruction, the provision of resources and opportunities, but it would be almost impossible based on possibility 'principle.' It is also in line with NaseriKaimvand et al. (2016)'s findings which considers 'possibility' as the most impossible parameters of PMP in Iranian EFL context. This shows that teachers' attention to socio-political change and transformation is less than other principles of PMP.

Regarding the third hypothesis of the present study 'teachers' attitudes of post-method principles do not differ significantly in terms of their experience, age, gender, field of study, education degree, city, and institute', the results revealed that, there was not a significant relationship between teachers' attitudes toward each of the five principles of PMP and gender, age, city, and institute, thus the third hypothesis was supported about them. But for teaching experience, field of study and education degree, the results showed significance in relation to some parameters. Concerning the relationship between teachers' attitudes of PMP and teachers' demographic factors, the findings about age and gender were consistent with those of Aboulalaei et al. (2016), but they were different in terms of teaching experience, education degree, and field of study.

In fact, teaching experience and field of study influence teachers' attitude of particularity, which deals with importance of context in a positive manner. Furthermore, education degree does not only affect particularity in a positive way but also influences practicality, which stresses the importance of involving teacher-generated theories of practice. Although all parameters of PMP require to be greatly emphasized to be actually implemented, possibility, which concerns sociopolitical change or transformation needs to be paid more focal attention, since even education degree cannot have positive effect on this parameter.

\section{Conclusion}

The present study attempted to study Iranian EFL teachers' attitudes towards PMP (post-method pedagogy) and its implementation in private language institutes. It also investigated the relationship between PMP principles and teachers' demographic features. The findings of the study show uncertainty about the actual emergence of PMP principles in EFL institutes in Iran and the fact that there is a long distance to the actual realization of principles of Particularity, Practicality, and Possibility, especially the last one. Moreover, there is a significant relationship between respondent teachers' familiarity of some principles of PMP and their experience, field of study, and education degree. Based on the results of the study, it can be argued that in order to approach the actual realization of PMP principles in EFL institutes in Iran, some issues and actions need to be taken into account. First, because of the importance of promoting language teachers' knowledge of PMP, the necessary means need to be provided by teacher education and training programs and in-service education. According to the results, all the three principles of PMP need to be addressed in Iranian EFL institutes, especially, Possibility which emphasizes the socio-political aspect. Second, in addition to teachers, all educational authorities, especially institute administrators should be aware of PMP and take necessary actions for its true realization.

The findings of this study can generally contribute to the body of knowledge of PMP literature. It is beneficial to theorizers to re-modify their theories; policy makers, language planners, curriculum designers, and textbook 
developers in Iranian educational system to adapt their educational needs to the reality of classrooms and approach actual implementation of PMP. Language instructors and teachers can also make use of the results of this study in their daily decisions. Relatedly, learners and their parents can understand their role better as active members. Among the limitations, it can be referred to the fact that this study was restricted to $80 \mathrm{EFL}$ teachers in two cities in one province of Iran, so it can be done with broader samples from different cities of the country. Additionally, in this study, the only method of data collection is questionnaire, therefore for better results, interview or observation can be added. For further studies, it can also be suggested that the same study might be done in secondary and tertiary educational context instead of private language institutes. Additionally, it seems that more studies need to be done in order to explore the factors which hinder the implementation of PMP principles both in private language institutes and high school context in Iran.

\section{References}

Aboulalaei, M. H., Poursalehi, J., \& Hadidi, Y. (2016). The familiarity of EFL teachers with post-method: Considering their field of study. English Language Teaching, 3(3), 83-104. https://pdfs.semanticscholar.org/6160/fa5ca78d2940bf584f17710147a8bf11dcab.pdf Accessed 20 June 2019.

Akbari, R. (2008). Post-method discourse and practice. TESOL Quarterly, 42(4), 641-652. http://doi.org/10.1002/j.1545-7249.2008.tb00152.x Accessed 27 June 2019.

Allwright, D. (1991). The death of the method (Working Papers No. 10). Lancaster, England: The University of Lancaster. The Exploratory Practice Center.

Bell, D. (2007). Method and post-method: Are they really so incompatible? TESOL Quarterly, 37, 325-336. http://doi.org/10.2307/3588507Accessed 27 June 2019.

Clemente, M. A. (2001). Teachers' attitudes within a self-directed language learning scheme. System, 29, 45-67. http://doi.org/10.1016/S0346-251X(00)000045-2 Accessed 27 June 2019.

Dörnyei, Z., \& Csizer, K. (2012). How to design and analyze surveys in second language acquisition research. In A MacKey \& S. M.Gass (EDs). Research methods in second language acquisition: A practical guide (pp. 7494). West Sussex: Blackwell.

Fahim, M., \& Pishghadam, R. (2009). Postmodernism and English language teaching. IJALS, 1, 27-54. doi:10.2211/IJALS.2011.51

Freeman, D. (1990). Interviewing in practice teaching. In J. Richards, \& D. Nunan (Eds.). Second teacher language education. Cambridge: Cambridge University Press.

Gholami, J., Bonyadi, A., \& Mirzaei, A. (2012). Postmodernism vs. modernism in Iranian non- governmental English language institutes. Modern Journal of Language Teaching Methods, 2(3), 128-143. doi.org/10.26655/mjltm.2012.2.3

Gholami, J., \& Mirzaei, A. (2013). Post-method EFL teaching in Iran: Barriers, attitudes and symbols. Research Journal of English Language and Literature (RJELAL), 1(2), 50-64. http://www.rjelal.com/RJELAL\%201.2.\%20pp\%2050-64.pdf Accessed 27 June 2019.

Hargreaves, A. (1994). Changing teachers, changing times. Cassell: London.

Hashemi, S. M. R. (2011). (Post)-Methodism: Possibility of the impossible? Journal of Language Teaching and Research, 2(1), 137-145. doi:10.4304/jltr.2.1.137-145

Hazratzad, A., \& Gheitanchian, M. (2009). EFL teachers' attitude towards post-method pedagogy and their students' achievement. Proceedings of the 10th METU ELT Convention. http://www.dbe.metu.edu/convention/proceedingsweb/Attitudes.pdf Accessed 1 July 2019.

Khany, R., \& Darabi, R. (2014). ELT in Iran: Reflection of the principles-based and post-method pedagogy in language teaching. Procedia-Social and Behavioral Sciences, 98, 908-916. doi:10.1016/j.sbspro.2014.03.499 
Khatib, M., \& Fathi, J. (2014). The investigation of the perspectives of Iranian EFL domain experts on post-method pedagogy: A Delphi technique. Journal of Teaching Language Skills, 6(3), 89-112. doi: $\underline{10.22099 / J T L S .2015 .2482}$

Khodabakhshzadeh, H., Arabi, M., \& Samadi, F. (2018). The relationship between English foreign language teachers' willingness with post-method pedagogy and their teaching effectiveness. International Journal of Instruction, 11(2), 425-436. http:// doi.org/10.12973/iji.201.11229a Accessed 1 July 2019.

Kumaravadivelu, B. (1994). The post-method condition: (E) merging strategies for second/foreign language teaching. TESOL Quarterly, 28(1), 27-47. http://doi.org/10.2307/3587197 Accessed 20 June 2019.

Kumaravadivelu, B. (1999). Critical classroom discourse analysis. TESOL Quarterly, 33, $453-484$. http://doi.org/10.2307/3587674 Accessed 27 June 2019.

Kumaravadivelu, B. (2001). Toward post-method pedagogy. TESOL Quarterly, 35(4), 537-560. http://doi.org/10.2307/3588427 Accessed 27 June 2019.

Kumaravadivelu, B. (2003a). Critical language pedagogy: A post-method perspective on English language teaching, World Englishes, 22(4), 539-550. doi: 10.1111/j.1467-971X.2003.00317.x

Kumaravadivelu, B. (2003b). Beyond methods: Macro-strategies for language teaching. New Haven, CT: Yale University Press.

Kumaravadivelu, B. (2006). TESOL methods: Changing tracks, challenging trends. TESOL Quarterly, 40(1), 59-81. http://dx.doi.org/10.2307/40264511 Accessed 27 June 2019.

Larsen-Freeman, D. (2005). A critical analysis of post-method: An interview with Diane Larsen-Freeman by Zia Tajeddin. ILI Language Teaching Journal, 1(1), 21-25.

Liu, D. (1995). Comments on B. Kumaravadivelu's "The post-method condition: (E) merging strategies for second/foreign language teaching": "Alternative to" or "Addition to" method? TESOL Quarterly, 29, 174177. doi: $10.2307 / 3587813$

Maghsoudi, N. (2016). Post-Mmethod pedagogy: A plausible choice in Iran? Studies in English Language Teaching, 4(2), 282-288. doi:https://doi.org/1022158/selt.v4n2p282 10.17569/tojqi.65871

Mardani, M., \& Moradian, E. (2016). Post-method pedagogy perception and usage by EFL teachers and learners and its limitations, symbols and viewpoints. International Journal of Language Learning and Applied Linguistics World (IJLLALW), 11(1). http://research.bkatu.ac.ir/_Pages/Research-En.aspx?ID=6950

Naseri Kaimvand, P., Hessamy, G. R., \& Hemmati, F. (2016). Post-method education: Its applicability and challenges in Iran. International Journal of Asian Social Science, 6(1), 21-34. $\underline{\text { doi:10.18488/journal.1/2016.6.1/ }}$

Pennycook, A. (1989). The concept of method, interested knowledge, and the politics of language teaching. TESOL Quarterly, 23(6), 589-618. https://doi.org/10.2307/3587534 Accessed 1 July 2019.

Prabhu, N. S. (1992). Second language pedagogy. Oxford: Oxford University Press.

Rashidi, N., \& Mansourzadeh, N. (2017). Post-method pedagogy and Iranian EFL teachers' understandings: Is a promising trend on the way? Issues in Language Teaching (ILT), 6(1), 55-82.doi:10.22054//ILT.2017.8419

Razmjoo, S. A., Ranjbar, H., \& Hoomanfard, M. H. (2013). On the familiarity of Iranian EFL teachers and learners with post-method, and its realization. .International Journal of Language Learning and Applied Linguistics World (IJLLALW), 4(1), 1-12. https://d1wqtxts1xzle.cloudfront.net/ Accessed 27 June 2019.

Saengboon, S. (2013). Thai English teachers' understanding of "post-method pedagogy": case studies of university lecturers. English language teaching, 6(12), 156-166. doi:10.5539/elt.v6n12p156

Safari, P., \& Rashidi, N. (2015). A move towards post-method pedagogy in the Iranian EFL context: Panacea or more pain? PASAA, 50, 95-123. doi:10.14456/pasaa.2015.4 
Shafiei, S., \& Zoghi, M. (2014).The familiarity of EFL teachers with post-method: Considering their attitudes towards methods and post-method. International Journal of Language Learning and Applied Linguistics World (IJLLALW), 7(4), 145-156. http://www.virasicence.com/thesis/author/120019 Accessed 27 June 2019.

Shafiqul Islam, A. B. M., \& Shuchi, I. J. (2017). Deconstruction of method-post-method dialectics in English language teaching. Journal of Language Teaching and Research, 8(3), 539-547. doi:http://dx.doi.org/10.17507/jltr.0803.12

Tasnimi, M. (2014). The role of teacher in the post-method Era. Express: An International Journal of Multidisciplinary Research, 1(3), 1-8. doi:dlwqtxts1xzle7.cloudfront.net/36811238/

Tekin, M. (2013). An investigation into novice teachers' views and beliefs about method and post-method pedagogy in Turkish EFL context. Turkish Journal of Qualitative Inquiry, 4(4), 55-69. doi:10.17569/tojqi.65871 